\title{
Total and HDL-Cholesterol Levels in the Serum of UVA-Irradiated Porphyric Rats
}

\author{
Wakio Torinuki and Takashi Miura \\ Department of Dermatology, Tohoku University School of \\ Medicine, Sendai 980
}

Torinuki, W. and Miura, T. Total and HDL-Cholesterol Levels in the Serum of UVA-Irradiated Porphyric Rats. Tohoku J. exp. Med., 1983, 139 (2), 223-224 - Total and HDL-cholesterol concentrations were measured in hexachlorobenzene-induced porphyric rats before and after repeated exposure to UVA for a month. No significant change in either concentration was seen. - cholesterol; HDL; porphyria; UVA

Porphyria cutanea tarda is characterized by elevated levels of uroporphyrin in plasma, urine and faeces (Moore et al. 1973). This hydrophilic porphyrin is probably attached to albumin and/or hemopexin in the circulation (Koskelo and Muller-Eberhard 1977). It is postulated that photodynamic action of the porphyrin excited by long-wave ultraviolet light (UVA) has an influence on various blood components, because UVA energy reaches in the dermal vessels. In this report, we measured total cholesterol and high density lipoprotein (HDL)-cholesterol levels in serum after UVA exposure of hexachlorobenzeneinduced porphyric rats in which the metabolic pattern seems to resemble that in porphyria cutanea tarda (Stonard 1974).

\section{Materials and Methods}

Induction of porphyric rats. Twenty Spraque-Dawley albino female rats, weighing about $200 \mathrm{~g}$, were fed a $0.25 \%(\mathrm{w} / \mathrm{w})$ hexachlorobenzene-diet for two months.

UVA irradiation. Porphyric rats were divided into two groups: 8 non-irradiated rats and 8 rats irradiated for a month. Hair was shorn with an electric clipper once every week. The light source consisted of four black lights (Toshiba FL-20BLB; Toshiba Electric Co.) which emit rays between 300 to $420 \mathrm{~nm}$, with a maximum at $360 \mathrm{~nm}$ (mainly UVA). The energy intensity was $3.9 \mathrm{~mW} / \mathrm{cm}^{2}$ at a target distance of $15 \mathrm{~cm}$ (radiometer UVR-305/ 365; Eisai Co.). The backs of the rats were irradiated with black lights for $5 \mathrm{hr}$ daily at a distance of $15 \mathrm{~cm}$, for a month. Blood samples were obtained from the abdominal artery of non-irradiated and irradiated rats. Total cholesterol and HDL-cholesterol levels in serum were estimated by the method of Burstein et al. (1970) and Allain et al. (1974), respectively.

\section{Results and Discussion}

The following skin changes were produced in the porphyric rats after UVA irradiation for a month: Erythema, erosion, crust, skin thickening and scarring. Regarding total and HDL-cholesterol contents in serum, however, no significant difference was observed between rats kept in the dark and irradiated rats (Table 1).

Received for publication, August 4, 1982. 
TABLE 1. Concentrations $(\mathrm{mg} / 100 \mathrm{ml})$ of total and HDL-cholesterol in
serum of hexachlorobenzene-induced porphyric rats

$\begin{array}{lccc} & \text { Total cholesterol } & \text { HDL-cholesterol } \\ \text { Before irradiation } & 128 \pm 25(8) & 101 \pm 21(8) \\ \text { Irradiation for a month } & 134 \pm 36(8) & 105 \pm 31(8)\end{array}$

mean \pm s.D. Numbers of observations in parentheses.

Recently, it has been indicated that there is an interaction between photo-excited porphyrin and blood components. Albumin inhibited the rate of photohaemolysis in erythropoietic protoporphyria, and a significant part of the albumin effect could be ascribed to its porphyrin-binding capacity, though most of the effect seemed due to an as yet unidentified property of this protein (Joenje et al. 1981). Irradiation of serum samples from patients with porphyria cutanea tarda resulted in activation of complement and generation of $\mathrm{C}_{5}$-derived chemotactic activity (Lim et al. 1981). Our data may suggest that active oxygen generated through energy transfer from photoexcited porphyrin in vivo has an influence on plasma proteins rather than on plasma lipids including cholesterol.

\section{References}

1) Allain, C.C., Poon, L.S., Chan, C.S.G., Richmond, W. \& Fu, P.C. (1974) Enzymatic determination of total serum cholesterol. Clin. Chem., 20, 470-475.

2) Burstein, M., Scholnick, H.R. \& Morfin, R. (1970) Rapid method for the isolation of lipoproteins from human serum by precipitation with polyanions. J. Lipid Res., 11, 583-595.

3) Joenje, H., Woutersen, R.A. \& Baart de la Faille, H. (1981) Inhibitory effect of plasma on photohaemolysis in erythropoietic protoporphyria. Dermatologica, 163, 285-294.

4) Koskelo, P. \& Muller-Eberhard, U. (1977) Interaction of porphyrins with proteins. Sem. Hematol., 14, 221-226.

5) Lim, H.W., Perez, H.D., Poh-Fitzpatrick, M., Goldstein, I.M. \& Gigli, I. (1981) Generation of chemotactic activity in serum from patients with erythropoietic protoporphyria and porphyria cutanea tarda. New Engl. J. Med., 304, 212-216.

6) Moore, M.R., Thompson, G.G., Allen, B.R., Hunter, J.A.A. \& Parker, S. (1973) Plasma porphyrin concentrations in porphyria cutanea tarda. Clin. Sci. mol. Med., 45, 711-714.

7) Stonard, M.D. (1974) Experimental hepatic porphyria induced by hexachlorobenzene as a model from human symptomatic porphyria. Brit. J. Haematol., 27, 617-625. 